Ty ö $p$ a $p$ e $r$ i t a

Working Papers

\title{
259 \\ Electricity \\ prices in the \\ Finnish \\ retail market
}

\author{
Eero Lehto
}


PALKANSAAJIEN TUTKIMUSLAITOS •TYÖPAPEREITA LABOUR INSTITUTE FOR ECONOMIC RESEARCH • DISCUSSION PAPERS

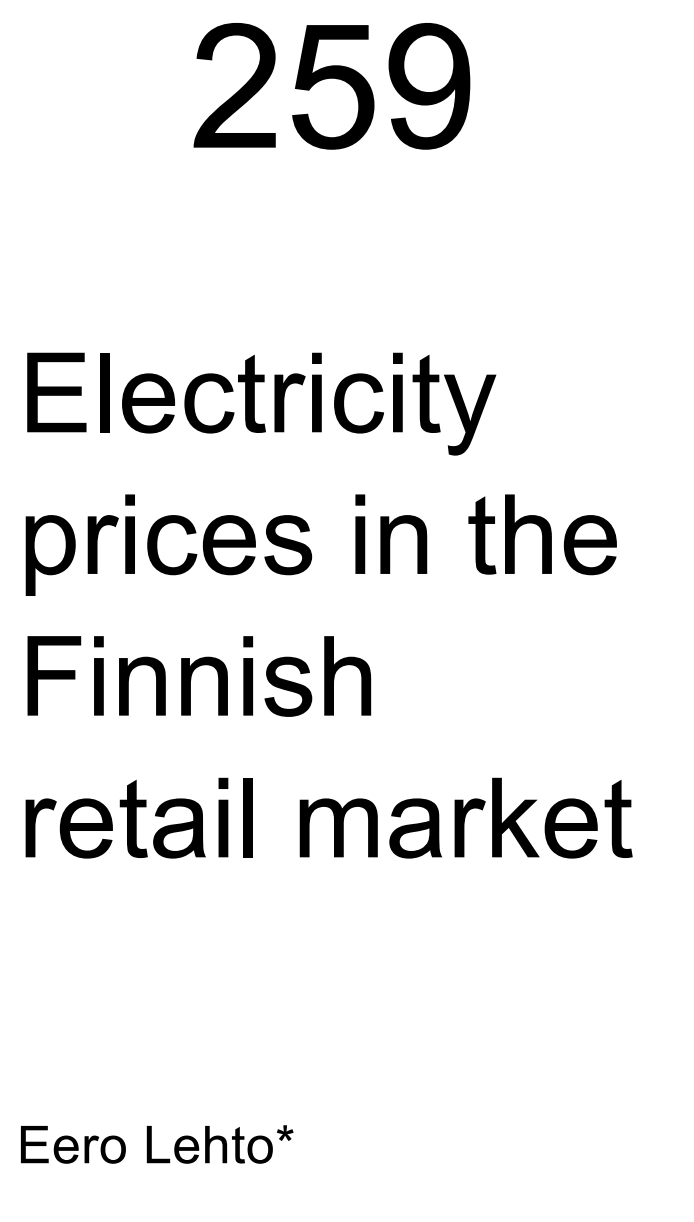

* Labour Institute for Economic Research, Pitkänsillanranta 3A, FI-00530 Helsinki, Finland. Fax:+358-9-25357332. Tel.: +358-9-25357330. E-mail: Eero.Lehto@labour.fi 
ISBN 978-952-209-080-5

ISSN 1795-1801 


\title{
TIIVISTELMÄ
}

Tämä tutkimus tarkastelee hinnoittelua Suomen sähkön vähittäismarkkinoilla. Tutkimuksessa analysoidaan sitä, miten omistusmuoto vaikuttaa sähköenergian listahintoihin. Myös sähkön hankintakustannusten vaikutusta näihin hintoihin arvioidaan. Tutkimuksessa perustellaan myös sitä, miksi shakoyhtiöiden käyttäytyminen voi osaltaan selittää asiakkaiden suhteellisen vähäistä halua vaihtaa sähkön toimittajaa. Tilastollinen analyysi perustuu sähköyhtiökohtaiseen aineistoon vuosilta 1997 - 2006.

\begin{abstract}
This study focuses, firstly, on the pricing of electricity in the Finnish retail market. In particular, the impact of the ownership structure on prices is tested empirically. Secondly, the influence of low-cost electricity sources on retail prices is considered. The question about whether the average fuel costs rather than the wholesale price determines the retail prices is thus addressed. The supply side behaviour characterized may explain the passivity of client activity in the seemingly competitive Finnish market.
\end{abstract}

Keywords: retail electricity prices, ownership structure, average cost pricing

JEL classification: L16, L21, L31

\section{INTRODUCTION}

Deregulation in the Finnish market started in 1995. In 1998 the electricity market was opened to competition with regard to consumers and other small customers. The required unbundling of distribution, generation and electricity sales enabled transparency in pricing and in this way promoted competition. According to the assessment of the European Commission, Finland belongs to the group of countries in which the level of competition is complete. ${ }^{1}$ Compared with other countries with a liberalised electricity retail market, however, client activity is low in Finland, as has been noticed by Perrels and Kemppi (2003) and Littlechild (2006). It is possible that the supply side behaviour and, especially, Finnish retailers' pricing strategy offer an explanation to the mystery of lame client activity.

\footnotetext{
${ }^{1}$ See European Commission (2004). The other countries in that group are UK, Sweden, Norway and Denmark.
} 
The mixed ownership of Finnish retailing companies - local private, municipal and purely investorbased - leads to the variety in motives which, for its part, is reflected in prices. On the other hand, the different types of forms of ownership may lead to other behavioural differences, for example, with respect to efficiency, which may also influence firms' ability to compete for customers. Vertical integration between generation and sales activity is also typical of the Finnish electricity retail market. This constitutes another factor which may influence pricing behaviour and retailers' abilities to compete. In all, there are good reasons for hypothesing that not only the customer characteristics but also the heterogeneity among retailers explain client behaviour.

Previous research has not explored the supply side behaviour in the electricity retail market in adequate depth. In the literature, rather few studies have, for example, investigated how ownership affects prices in the electricity retail markets. In the United States the price regulation of retail electric providers - which has treated the large investor-owned utilities even differently from smaller electric co-operatives or municipal utilities - has obscured the comparison of price-performance between different types of ownership. Furthermore, the fact that in the USA the locally owned utilities tend to be small and rural compared with large-size urban and investor-owned utilities makes it more difficult to analyse the impact of the form of ownership on retail prices. Anyway, Petersen (2006) discovered that the rates charged to residential customers in the Rocky Mountains and the southwestern United States do not differ by the type of utility. Hollas et al. (1994) focused on the pricing in the Tennessee Valley of the two not-for-profit forms of utility: the municipal and the co-operative. According to them the co-operatives tend to set their prices in a more profit-oriented manner than municipalities do. The other evidence from the United States is more anecdotal. The role of large-scale operation is recognized and so, for example, the EIA (Energy Information Administration) (2007) believes that the investor-owned electric utilities set the lowest prices owing to economies of scale.

The electricity retail market in the Nordic countries would be much more suitable for the analysis, which concerns the role of ownership, than the U.S. market. Firstly, the markets in Denmark, Finland, Norway and Sweden were opened up to competition in electricity generation and retailing in the years 1991 - 2000 (see Amundsen and Bergman, 2007) and so those countries have not been subject to any regulatory controls on prices or other contract terms (see Littlechild, 2006). Despite the fact that the vertical integration of retailing, generation and distribution is common, accounting and management are more or less separated in these activities for regulatory needs, and also have the purpose to enable the required transparency for competition. Apart from that, in addition to the increased role of investor-owned companies, various types of local ownership still play an important role in the Nordic electricity retail market. The utilities may also have their own power plants or they may own shares in hydroelectric or other types of power-production in other firms.

Against this background one would have imagined that the relevance of the ownership structure would have been investigated in an analysis that considers pricing in the Nordic electricity retail 
market. But even in these markets the role of ownership is mostly considered as being rather insignificant. For example, in the Norwegian markets where most retailers operate only in their own regions there are a number of small companies that are committed to serving their local clients at reasonable prices. Von der Fehr and Hansen (2008), however, consider the influence of low pricing obliged by local government owners - as limited and unimportant for the whole market. So it is rather commonly believed that most regional retailers charge prices at around a competitive level which is more or less determined to be the wholesale electricity price. This conclusion, though, remains vague, insofar as any statistically significant evidence is provided that would indicate the irrelevance of notfor-profit pricing behaviour. In the Finnish market the relevance of not-for-profit pricing is important, as will be shown in this study. However, Littlechild (2006) states that in the Finnish market municipal ownership reduces retailers' ability and incentive to compete for customers.

It also seems that in the Scandinavian market both vertical integration and local ownership may affect both pricing and so also customer activity (to switch the operator or to renegotiate the contract) in the retail market. Defeuilley (2009) has introduced a new and well-founded approach to interpret customer mobility in the electricity retail market. This analysis could be supplemented by considering the supply side behaviour too. It is obvious that pricing which relies on low-cost electricity sources or which is even targeted to benefit the local customers may freeze customer mobility and give a natural explanation to unexplained differences in customer activity between various countries where competition in the electricity market is free.

Amundsen and Bergman (2007) have considered the electricity retail markets in Sweden and Norway and regard vertical integration as a competitive advantage with reference to the situation in Sweden. According to them, all retailers suffer from volatile demand and wholesale prices. The lack of an efficient market against the price and quantity risks makes the situation difficult, but integrated retailers can control these risks by their own electricity generation and, in this way, obtain a competitive advantage with respect to the other retailers. It is possible that this obvious cost advantage stems from a lack of hedging against price risks, as Amundsen and Bergman (2007) put it. But even if a hedging mechanism is available, it is costly. Furthermore, hedging costs seem to decrease in a firm's size (see Haushalter, 2000), and for that reason the appearance of a hedging facility in the electricity retail market would fail to solve the financial problems of smaller and independent entrants whose activity was supposed to enliven a lame competition situation.

It is also noteworthy that small clients in the electricity retailer market are more risk averse than the retailers, and so retailers may obtain extra benefits when removing the price risk faced by their customers at their own expense. This even emphasizes the competitive advantage of those retailers who are able to bear or eliminate price risks. As a consequence, the competitiveness of such retailers - which do not have their own generation - is further attenuated. 
Empirical findings hint that incumbents that have their own production follow average cost pricing and decide upon a standard variable tariffs contract which flattens the impact of highly volatile wholesale prices on the client prices. This concerns at least the Nordic market - as noticed by Littlechild (2006). According to Zarnikau et al. (2007) and Kang and Zarnikau (2009) in Texas the average cost tend to reflect average fuel costs in the areas where competition was not allowed. In the areas open to competition the retail prices, contrastingly, started to follow the price of gas which is the marginal fuel used for generation.

Whereas a decent statistical analysis of the ownership's impacts on pricing in the retail electricity market is practically lacking, studies which consider the ownership's impact on productivity in the respective market (including distribution) exist. Hjalmarsson and Veiderpass (1992) obtained a result according to which different types of ownership had no response on efficiency. But later Kumbhakar and Hjalmarsson (1998) - again using the Swedish data - found that privately owned companies were relatively more efficient than municipal companies or utilities. Berry (1994) analysed productivity in the U.S. retail electrical market and obtained a result which suggests that the rural co-operative sector is less efficient than the investor-owned sector. These results are not surprising and they make one believe that investor-owned retailers, possibly being more efficient than others, are not vulnerable to the possible tendency of locally owned retailers to keep prices at a low level.

This study addresses pricing in Finland's electricity retail market. The impact of the ownership structure on prices is empirically tested. The influence of the vertical integration of sales activities and generation (and other low-cost electricity provision) on prices is also explored. This study contributes to previous research by analysing retail pricing in the firm level data, which makes it possible to control the firm characteristics. By means of investigation of the impact of ownership changes, the panel form of the data set also allows us to control for selection bias due to unobservables.

The paper proceeds as follows. In Section 2 we discuss the Finnish retail electricity market theory in more detail and introduce a central hypothesis to be tested. Section 3 contains a description of our data. Section 4 reports our results and the last section concludes. 


\section{THE BEHAVIOUR OF THE ELECTRICITY RETAIL MARKET AND THE HYPOTHESIS TO BE TESTED}

\subsection{The characteristics of the Finnish retail market}

Electricity sales in the Finnish retail market are no longer subject to licensing. The regionally exclusive right to sell electricity has been removed from electricity retailers. Anyone can become an electricity retailer. In each area the incumbent distributor (Distribution System Operator, DSO) is, however, obliged to sell electricity at a reasonable price to customers and to other small clients (obligation-to-deliver clients, OD-clients). These prices shall be publicly available and shall not discriminate within each group of clients. The purpose of this institution was to safeguard the interests of small electricity users. In practice, the Energy Market Authority has not regulated these prices, called public list prices (or obligation-to-deliver prices).

The Electricity Market Act (EMA) was introduced in Finland in 1995. From the beginning the EMA presumed that distribution, generation and electricity sales were separated from each other. This meant that a separate income statement and, in capital-intensive operations, a separate balance sheet, had to be prepared for each of these operations for each financial period. In the municipally owned utilities, the electricity business had to be separated from the municipality's economy. Since 2004 the EMA has been changed so that only the separation of distribution from the rest of the activities was required. Later, from the beginning of 2007, the legal separation of distribution was applied to about the six largest grid operators (see e.g. Littlechild, 2006). Implementing this amendment made the largest operators restructure their organisation.

For example in the year 2001, the regional distributors and other retailers sold about 53 per cent of all net consumption in Finland. According to the survey made by the Finnish Electricity Association in 2003, almost 80 per cent of household customers and two thirds of clients of DSOs have remained totally inactive. ${ }^{2}$ Only 5 per cent of household clients have gone so far that they had switched the operator by 2003 . The remaining 15 per cent have renegotiated their contract with an incumbent. It also noteworthy that active clients (including firms) are, on the average, larger than passive clients. So, in terms of the electricity purchased, the share of active clients is almost 60 per cent. In the retail market the electricity to OD-clients (the passive clients) is sold in the form of variable price contracts. In these contracts the supplier may adjust the contract price when he finds that it is appropriate, following changes in supply costs (see Olsen et al., 2006).

\footnotetext{
${ }^{2}$ See The Finnish Electricity Association and Statistics Finland (2003). Later Lewis et al. (2007) have assessed that by 2007 about 70 per cent of Finnish households still bought their electricity from obligatory supplier with standard terms.
} 
In the Finnish electricity retail market the incumbents are obliged to sell electricity in their old, traditional areas but they are also entitled to challenge the incumbent in the other areas. Most of all the competitors are traditional incumbents. According to the survey of the Energy Market Authority (2005), around 46 per cent of regional DSOs in 2005 did not, however, supply electricity outside their own area. Of all the DSOs the market share of the four largest retailers has been 35-40 per cent in the market for small and medium-sized customers. The role of non-DSO competitors, as well as their market share, has been rather small.

In recent years the ownership structure has undergone remarkable changes in the Finnish market. Large investor owned companies ${ }^{3}$ have acquired locally owned retailers. It is worth noticing that the biggest acquisitions have, however, concerned large companies in rural rather than urban areas. In the biggest cities - excluding Espoo - the DSOs are owned by the municipality. In this respect, the situation is different from that in many other countries in which local ownership and co-operative activity are alive only on the periphery.

In 2001 the DSOs themselves generated almost one third of all electricity - which they supplied - in combined heat and power (CHP) plants. DSOs also have their own hydro-power, but not much. (The exact figure is not available.) Some DSOs have also acquired equity stakes in electricity generating companies (often hydro-power generators). DSOs are, however, very heterogeneous as regards the structure of electricity provision, and thus many retailers acquire most of their electricity supplies in the wholesale market.

\subsection{The interaction of supply side and customer behaviour}

There are good grounds to assume that in Finland the behaviour of DSOs in the retail market has also been two-fold. For the investor-owned company which maximizes profits, the opportunity cost to retail sales is the wholesale price, whereas for local companies - who are committed to serving the local community - such an opportunity cost does not exist. The latter entity sets prices according to average costs so that the margin between the retail price and the average costs covers the expenses. Let $A C^{j}$ denote the retailer j's average electricity purchase costs. Then

$$
A C^{j}=\sum_{i=1}^{n} C_{i} X_{i}^{j}
$$

\footnotetext{
${ }^{3}$ Particularly the German E.On and the Finnish Fortum and the Swedish Vattenfall have acquired local retailing companies. Although the state owns majority in Fortum and 100 percent in Vattenfall, these companies follow the principles of corporate governance and act as profit maximizers in the electricity retail market.
} 
where $C_{i}(\mathrm{i}=1, \ldots, \mathrm{n})$ is the cost of an item i (being the same for all operators) in electricity purchases and $X_{i}^{j}$ is the respective amount for an operator $\mathrm{j}$. Assume that retailer $\mathrm{j}$ sets her price $P^{j}$ according to $A C^{j}$. Then

$$
P^{j}=A C^{j}+m^{j}
$$

where $m^{j}$ is the price margin to cover the costs of operation and a required profit. Let $C_{k}$ denote the price for purchases from the wholesale market. The profit maximizing retailer sets her retail price then according to

$$
P^{j}=C_{k}+m^{j}
$$

If the retailer, who tends to set prices according to average costs, has no alternative sources to provide electricity than the wholesale market, the price will follow the pattern (3). So, abstracting from differences in $m^{j}$, it is evident that pricing according to (2) actually deviates from (3), only if the retailer has other (low-cost) sources of electricity than purchases from the wholesale market.

\section{Figure 1. Retail prices for households in an apartment and the wholesale price for Finland.}

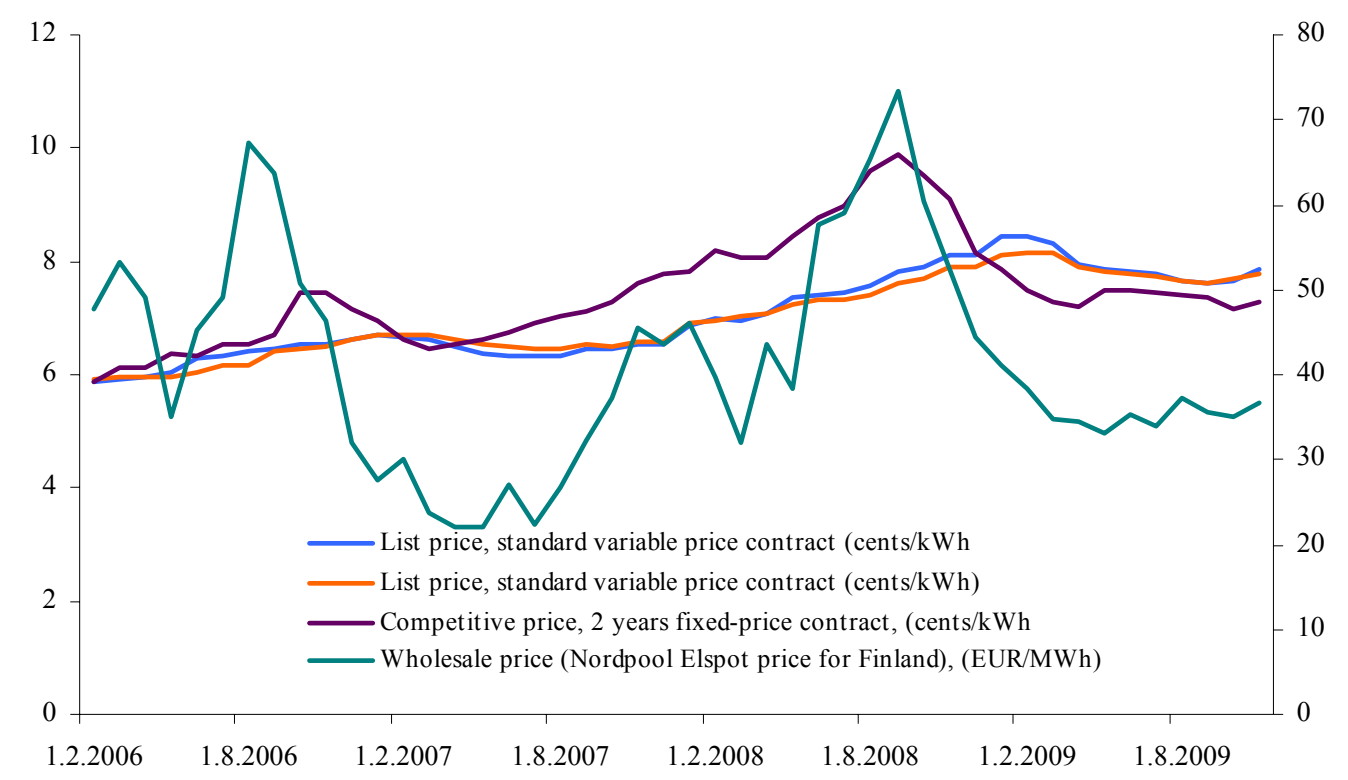

Figure 1 indicates that competitive prices in the variable price contracts tend to closely follow the respective list prices. But among the competitive contracts the fixed price contacts are often more popular (see Kinnunen, 2004). The prices in the latter contract follow the wholesale price more closely than the prices in the variable contracts. They also customarily exceed the price level in the 
variable price contracts when the wholesale price is high. Spot contracts with even closer connections to wholesale prices have also become more general. ${ }^{4}$

The fact that prices in competitive fixed price contracts follow wholesale prices much more closely than prices in variable price contracts indicates that pricing in the latter contracts corresponds to average costs pricing. These figures do not yet tell whether the incumbents - who have low-cost generation sources and other cheap sources - tend to sell the risk-averse customer stable price contracts (although formally variable price) in a profit-maximizing manner or whether the target is really to transfer the rents obtained to local clients in the form of low and stable prices. Johnsen and Olsen's recent study (2008) shows that retail prices for households develop very smoothly in Finland. Volatility is much greater in other Nordic countries.5 The low level of list prices compared with spot prices makes the authors conclude that suppliers have sold electricity with considerable losses.

The wholesale price (in Figure 1) is Finland's "area price" in the integrated Nordic wholesale market.6 It is closely related to the so-called "system price", which is determined for each hour by the intersection of the aggregate supply and demand curves representing all bids and offers for the entire Nordic region. In the integrated system, plants with lower costs (to produce electricity) are started up first so that the last plant to start up with the most expensive variable costs determines the "system price" 7. From these definitions it follows that typically $C_{k}>A C^{j}$. Typically, the marginal costs of coal condensing fix the system price. Its volatility is, however, largely caused by fluctuations in demand and variations in water reservoirs in Norway and Sweden.

The sharp variations in the wholesale price also affect competition between non-profit DSOs and their competitors. When the wholesale price rises, those competitors - who offer fixed-price contracts improve their situation with respect to incumbent DSOs, as a rule. This derives from the fact that the wholesale price often decreases with heavy rains in Sweden and Norway. The average electricity procurement costs of many urban DSOs - to whom a district heat CHP is an important source of electricity - do not, however, necessarily decrease. But in dry seasons and during high demand the situation is reversed: the competition situation of urban DSOs, especially, improves.

\footnotetext{
${ }^{4}$ This indicates that in the Finnish market the space for profitable market entry has remained narrow unlike in the UK where high incumbent prices have created a lucrative business prospects for new non-incumbent suppliers (see Giulietti et al., 2010).

${ }^{5}$ This also appears in the report of Nordic Energy Regulators (2006).

${ }^{6}$ In the Nordic market area prices may, however, differ from each other. So, for example, the price for Finland can deviate from other prices owing to congestions (see, Nordic Energy Regulators, 2006). The price mechanism in the Nordic wholesale market is also considered by Perrels and Kemppi (2003).

${ }^{7}$ The respective mechanism in England is described, for example, in Green (1994).
} 
The price mechanism in the retail market also has its own impact on customer behaviour. Let us explore customer behaviour more closely. Assume for the sake of simplicity that customers live only two periods ( $\mathrm{t}$ and $\mathrm{t}+1$ ). A utility $u_{t}^{D}$ is supposed to accrue to the customer of a local DSO which sets the retail price according to the average costs. Respectively, a utility $u_{t}^{C}$ is obtained in a customer relationship with a competitor who sets prices according to the wholesale price. $u_{t+1}^{D, e}$ and $u_{t+1}^{C, e}$ are the respective expected utilities in period $t+1$, and $\theta$ denotes the switching costs. A parameter $\theta$ is simply assumed to be fixed, although it evidently varies a lot from one client to another, and not only on strict economic grounds as suggested by Defeuilley (2009). ${ }^{8}$

Let us first consider a situation in which a client is originally attached to a local DSO. The client's pay-off is

$$
u_{t}^{D}+\delta u_{t+1}^{D, e}
$$

when she does not switch the operator. In (4) $\delta$ is a discount factor. Switching in period t to a competitor and then back to a local DSO in period $t+1$ would produce an intertemporal utility

$$
u_{t}^{C}-\theta-\delta \theta+\delta u_{t+1}^{D, e}
$$

Switching in $\mathrm{t}$ to a competitor and staying with it in $\mathrm{t}+1$ yields

$$
u_{t}^{C}-\theta+\delta u_{t+1}^{C, e}
$$

Finally staying with a local DSO in $\mathrm{t}$ and switching to a competitor in $\mathrm{t}+1$ gives a utility

$$
u_{t}^{D}-\delta \theta+\delta u_{t+1}^{C, e}
$$

Let us consider more closely the terms under which it pays to switch in period t. Suppose that

$$
\text { (8) } \quad u_{t+1}^{D, e}>u_{t+1}^{C, e}+\theta
$$

Then policy (5) is superior to policy (6) and then policy (4) is also superior to policy (7). It pays to switch to a competitor, if the utility in (5) is larger than the utility in (4). So, it is required that

$$
\text { (9) } \quad u_{t}^{C}>u_{t}^{D}+\theta+\delta \theta
$$

\footnotetext{
${ }^{8}$ Von der Fehr and Hansen (2008) considered customer behaviour in the Norwegian retail market. The contradiction between the apparent ease of switching and the actual customer stickiness becomes also evident from their empirical study.
} 
This shows that when a client assesses that a DSO will be superior to a competitor in the future so that (8) is valid, the terms of switching in the current period become very strict. If, opposed to that, the competitor and the DSO are assessed as being equally good in the future, the client switches to competitor in period $t$, if

$$
u_{t}^{C}>u_{t}^{D}+\theta
$$

It is rather conventional to assess the terms of switching behaviour in terms of the condition (10) which, however, suffers from myopia when $u_{t+1}^{D, e} \neq u_{t+1}^{C, e}$. On the other hand, comparing (10) with (9) shows how sensitively the current choices depend on future expectations.

In the situation in which a client is originally attached to a competitor but wishes to switch to a DSO in $\mathrm{t}+1$, because the condition ( 8 ) is valid, the client chooses a competitor in the current period, if

$$
u_{t}^{C}>u_{t}^{D}+(1-\delta) \theta
$$

It is self-evident that current choices are contingent on the original position of the client, because switching is costly. This can be seen if one compares the condition (11) with the condition (9). The above analysis also shows that it is rather difficult to understand customer behaviour in the heterogeneous retail market by focusing only on switching costs.

\subsection{The focus of this study and the questions to be answered}

In this empirical study, price-setting in the retail market will be considered. The purpose is not only to obtain knowledge of pricing practices but also of its possible implication on client behaviour in the formally free electricity retail market. The data set available for this study allows one to investigate only the determination of list prices (or obligation-to-deliver prices). These prices are, however, the most remarkable prices in the Finnish retail market. They also have an impact on competitive prices. The two main questions - which are to be answered in this study - are the following:

(i) Does ownership have a systematic effect on the level of electricity retail prices?

(ii) Does the retailers' (fuel) cost structure influence its prices?

In addition, the question as to whether the retailer's larger size - owing to the presence of scale economies - decreases prices is also explored. All in all, this study aims to give simple, clear answers. 


\section{THE DATA DESCRIPTION AND ECONOMETRIC MODELLING}

\subsection{The Data}

This study uses the data on all the DSO retailers in the Finnish market in the years $1997-2006.109$ DSO retailers existed in 1997 but, owing to acquisitions and the structural consolidation of sale activities, only 70 retailers remained in the year 2006. We have, however, constructed a panel data which describes retailing in the original 106 distribution areas. So even if a retailer has been merged, it continues its life in the data with the characteristics of the parent company.

The data of the list prices of electrical energy (excluding distribution component) in various customer groups in each area is provided by the Finnish Energy Market Authority (FEMA). The data for the years 2007 and 2008 was not available. The data is annual, but, owing to data restrictions, the retail prices actually describe the situation in August of every year. Also, the data on turnover comes from FEMA. Information about ownership changes and about the structure retailer's electricity provision has been separately gathered for this study. Information about ownership is based partly on data used in Lehto (1994). The data is then updated, using various information sources like the electricity companies themselves, FEMA and the Finnish Competition Authority. The data on the electricity provision is obtained from the old statistics of the Association of Finnish Electric Utilities and by investigating the firms' annual and other interim reports and their internet pages.

The electricity retailers are classified as belonging to 5 different groups, which are municipally owned, private but locally owned, investor-owned, those retailers in which investors have a remarkable minority stake, and co-operatives. Most urban companies are still municipally owned. Locally owned private utilities are often rural companies that are owned by local entrepreneurs, farmers and private persons. Since the beginning of the 1990s the companies owned by outside investors (Fortum, Vattenfall, Graninge and E.ON) have acquired locally owned companies. In some cases they acquired only a remarkable minority stake, typically more than 30 per cent. The role of classical co-operatives in Finland has been minor. 
Table 1 The ownership structure of DSOs in the year 1997's distribution areas.

\begin{tabular}{llllll}
\hline Year & Municipal & Local private & $\begin{array}{l}\text { Investor } \\
\text { owned }\end{array}$ & $\begin{array}{l}\text { Investor with } \\
\text { minority stake }\end{array}$ & Co-operative \\
\hline 1997 & 68 & 20 & 9 & 3 & 6 \\
1998 & 70 & 17 & 11 & 3 & 6 \\
1999 & 67 & 16 & 14 & 3 & 6 \\
2000 & 63 & 16 & 18 & 3 & 6 \\
2001 & 63 & 15 & 20 & 3 & 5 \\
2002 & 64 & 14 & 21 & 3 & 4 \\
2003 & 60 & 13 & 21 & 10 & 2 \\
2004 & 60 & 13 & 21 & 10 & 2 \\
2005 & 60 & 13 & 21 & 10 & 2 \\
2006 & 60 & 13 & 21 & 10 & 2 \\
\hline
\end{tabular}

On some occasions a larger municipally owned DSO has acquired another municipally or private and locally owned DSO. Mostly, however, the investor-owned companies have obtained other companies.

Exact information about electricity purchases and generation is not available. The dummy variables have, however, been constructed to describe the existence of low-cost generation and low-price purchases (based on ownership stakes). These variables tell whether a DSO has

- $\quad$ its own CHP (district heat generation)

- its own hydro-power (generation)

- $\quad$ stakes in hydro-power, (of some other hydro-power companies, especially in Northern Finland)

- $\quad$ stakes in other power, (in particular of a PVO company which also has nuclear power).

Figure 2. The electricity provision, the average participation rate in the years 1997-2006.

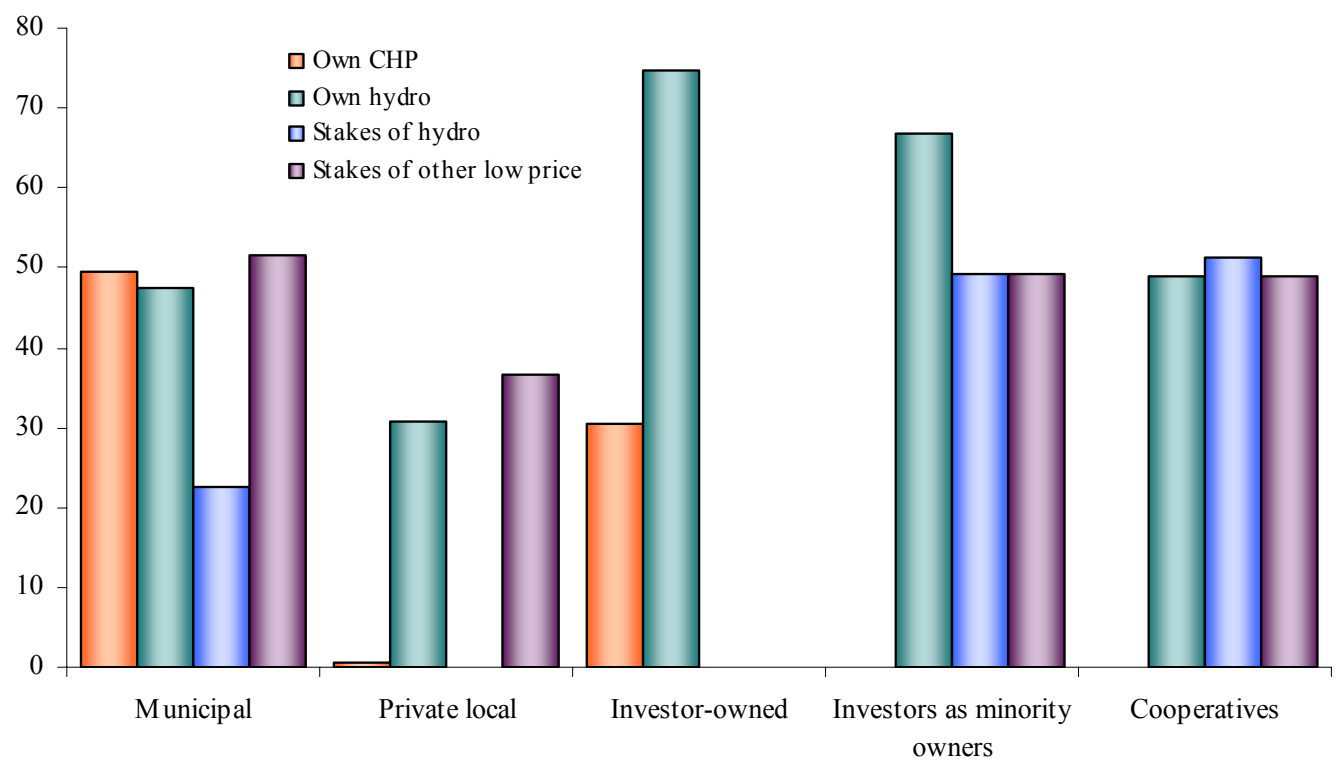


According to the information given in Figure 2, on the average 50 per cent of all municipal retailers generated electricity via their own CHP plant during 1997 - 2006. One can consider one's own CHP as a more significant source of low-cost energy than other sources. This gives a competitive advantage to municipally owned companies, which more often than not have their own CHP generation. Besides municipal companies, only some investor-owned companies have their own CHP production. One's own hydro-power generation is more evenly distributed over various ownership groups than one's own CHP plant. Most of the hydro-power capacity in Finland is, however, owned by manufacturing firms and large power companies. Some retailing firms have their own hydropower, but it is often small and therefore a rather meaningless source of energy. The stakes in other hydro-power generators and other power plants entitle a retailer to buy cheap electricity which can be economically important for the retailers. In all, low-cost electricity provision benefits electricity retailers in various ownership groups in very different degrees.

The retailer's size is expressed by the nominal turnover in euros. The dummy variables for three groups of different sizes have also been constructed. The retailer is classified as being

- $\quad$ large, if its annual turnover exceeds 100 million euros in the year 2002;

- medium size, if its turnover exceeds 10 million euros in the year 2002;

- small, if its turnover is less than 10 million euros in the year 2002.

If the turnover varies around these limits, the criterion is the maximum value and the retailer is, however, constantly classified as belonging to the same size group. For the utilities which were acquired before 2002, size criteria are determined on the basis of the deflated values of the turnover limits from the year 2002.

- Statistical analysis explains the determination of the DSOs' (Distribution System Operators')

- list prices (or obligation-to-deliver prices) for the following consumer groups:

- $\quad \mathrm{P} 1$, household in an apartment (fuse 1x25 A, consumption $2000 \mathrm{kWh} /$ year)

- $\quad \mathrm{P} 2$, household in single house (fuse $3 \times 25 \mathrm{~A}$, consumption $5000 \mathrm{kWh} /$ year)

- $\quad$ P3, single house with direct electric heating (fuse 3x25 A, consumption $18000 \mathrm{kWh} /$ year)

- $\quad$ P4, single house with partly accumulating electric heating (fuse $3 \times 25 \mathrm{~A}$, consumption $20000 \mathrm{kWh} /$ year)

- $\quad$ P5, Agriculture (fuse $3 \times 35 \mathrm{~A}$, consumption $10000 \mathrm{kWh} /$ year)

- P6, Agriculture, direct electric heating, fuse 3x35 A, consumption $35000 \mathrm{kWh} /$ year

- $\quad$ P7, Small-scale industry (consumption $150000 \mathrm{kWh} /$ year, demand $75 \mathrm{~kW}$ )

DSOs set list prices for the larger industry, too. But because in practice this industry buys directly from the wholesale market, these prices are not relevant. 


\subsection{The models}

The determination of list prices $P_{i}(\mathrm{i}=1, \ldots, 7)$ is first analysed by estimating the model

$$
\log \left(P_{i t}\right)=c_{i}+\mathrm{A}_{i}{ }^{\prime} X_{i j t}+\Omega_{i}{ }^{\prime} Y_{i k t}+\Psi_{i}^{\prime} S_{i m}+Y E A R+\varepsilon_{i t}
$$

for retailer $\mathrm{i}$ with pooled regression. Above in (12) $c_{i}$ is constant, $X_{i j t}$ is the vector of $\mathrm{j}$ ownership dummies, $Y_{k t}$ is the vector of k electricity provision dummies, $S_{i m}$ is the vector of $\mathrm{m}$ size indicators. Alternatively, $S_{i m}$ is replaced by the $\log$ of nominal turnover. $Y E A R$ describes the year dummies. Above all, these dummies capture the impact of the general wholesale price on list prices.

In another analysis the ownership changes are analysed using the difference-in-differences (DID) approach, which, since the work of Ashenfelter and Card (1985), has become widespread to analyse this kind of situations. For example, within this framework, Bertrand and Zitouna (2008) have explored the ownership changes.

Next, the ownership variables, which are needed in the DID approach, are specified. Let LO $=1$, if ownership is local (either municipal, local private or co-operative). Otherwise LO $=0$. In fact, when $\mathrm{LO}=0$, the retailing firm is either investor-owned or such a firm in which an outside investor possesses a large minority of shares. In the data set of this study LO has changed in 19 cases from 1 to zero. Variable LO has not changed reversely. Using LO, the following variables are then constructed:

Basic $=1$, if $\mathrm{LO}=1$ in all years. Otherwise Basic $=0$.

Propens $=1$, the value of LO has changed in some year. Otherwise Propens $=0$.

Change $=1$ during that year and after it when LO changes from 1 to 0 . Otherwise (i.e.

before the change and when no change occurs) Change $=0$.

The constructed variables allow us to estimate the model

$$
\log \left(P_{i t}\right)=c_{i}+\alpha_{i} \text { Basic }_{i}+\beta_{i} \text { Propens }{ }_{i}+\mu_{i} \text { Change }_{i t}+\Omega_{i}{ }^{\prime} Y_{i k t}+\Psi_{i}^{\prime} S_{i m}+Y E A R+\varepsilon_{i t} .
$$

In (13) Propens captures the possible difference between 'the treatment and the control groups', in other words, between those that become subject to a change of ownership, and the rest of retailers. Because some firms are originally (and all the time) owned by outside investors, a variable Basic has also been added to the model to control the differences between the firms to which Propens $=0$ but a variable Basic may have different values. By controlling Propens and Basic the model identifies those that are subject to a change of ownership, those that are locally owned all the time and finally those that are investor-owned all the time. YEAR dummies control the time effects on list prices. After introducing these variables the coefficient of Change then reveals the real impact of the change of 
ownership that has been considered. This procedure then eliminates the selection bias related to the time-invariant individual characteristics of retailers in control and treatment groups.

All the regressions are estimated by OLS

\section{THE RESULTS}

Figures 3 and 4 describe the yearly averages for household electricity P1 in each ownership group. These figures already indicate that the price is highest when the company is owned by investors or when the investors have, at least, a remarkable minority of shares. Deeper econometric analysis is, however, needed to control the effect of other influential firm-specific variables.

Figure 3. The price of electricity for households (P1) in different ownership groups.

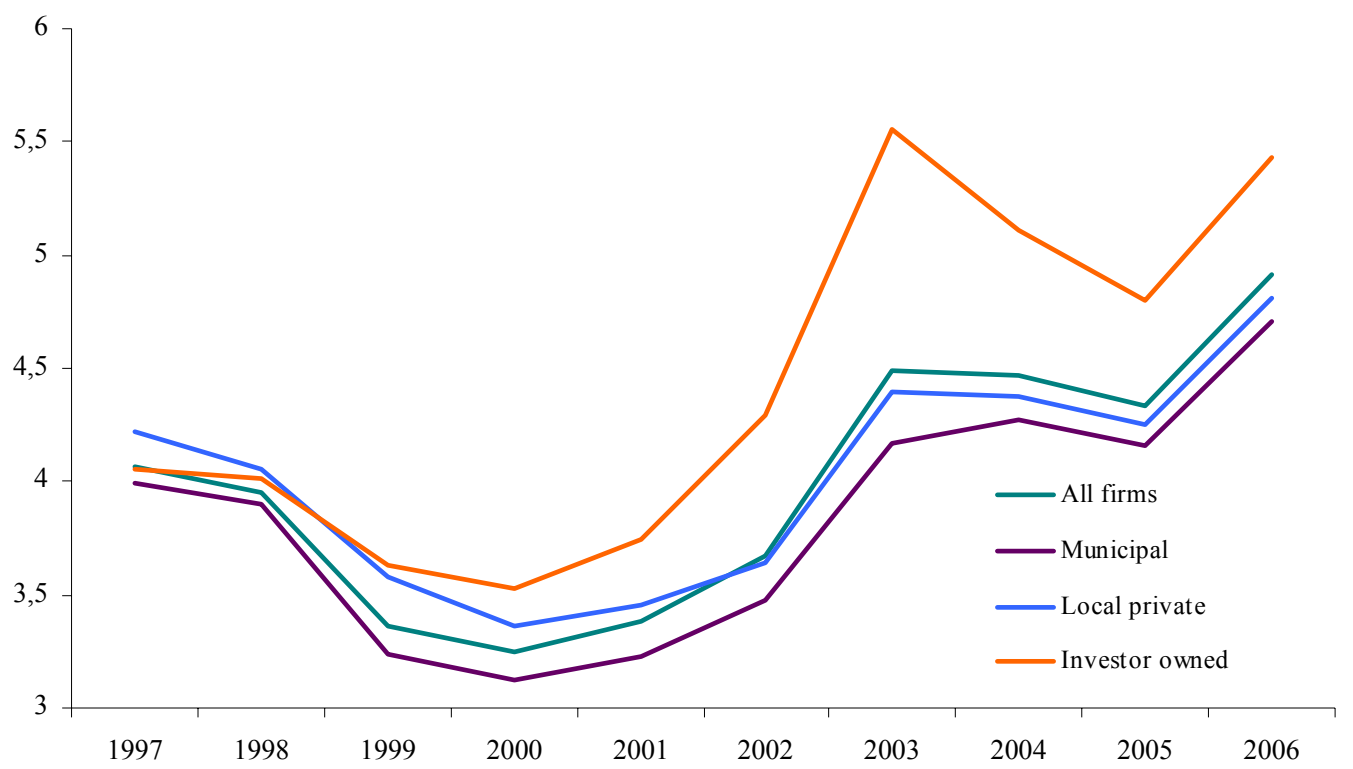


Figure 4. The price of electricity for households (P1) in different ownership groups.

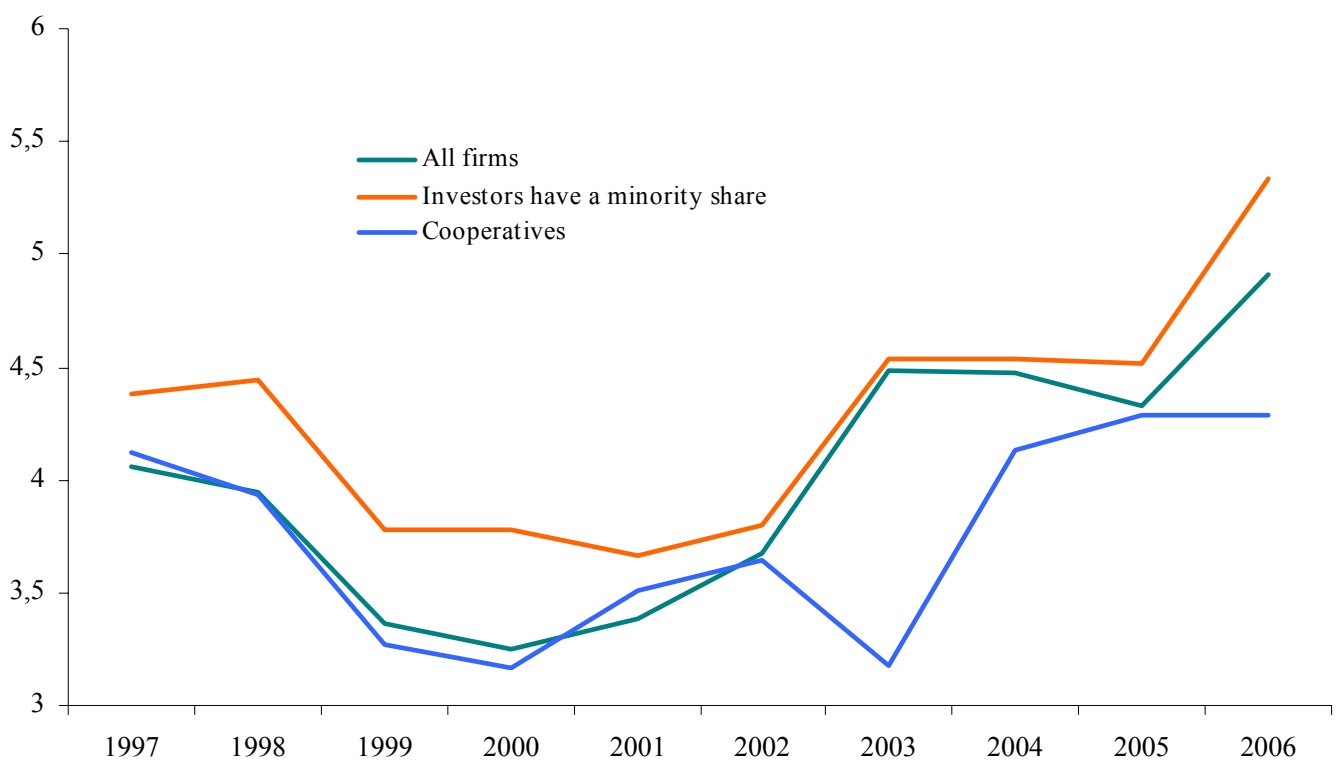

The annual averages of the electricity price for retailers which are grouped according to their sources of electricity do not give a clear picture of the impact of "the low-cost" sources. Because almost all firms have access to some low-cost source, "all firms" in Figure 5 is not necessarily a good reference. A proper econometric analysis is undoubtedly needed.

Figure 5. The price of electricity for households (P1) for different sources to obtain electricity.

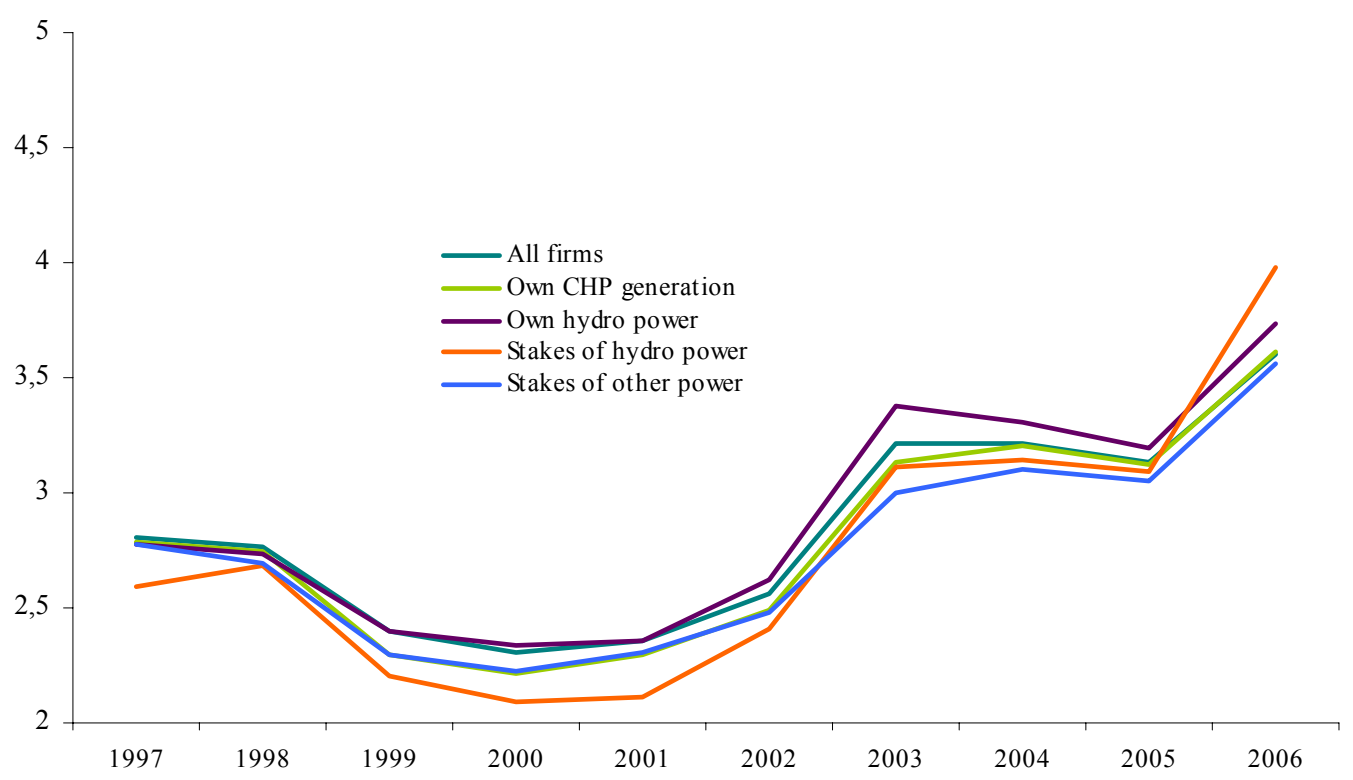

The estimation results obtained from the model (12) are reported in Tables 2 and 3 and in Table A1 in Appendix A. Because the ownership dummies and size dummies are linearly dependent, one of these dummies in both groups must be dropped off. The municipal ownership dummy and large size 
dummy are omitted and so the coefficients of other dummies tell what the difference is with respect to the omitted dummy. In Table 2, for example, the coefficient 0.051 for the 'local private' dummy (in the first column) shows that in the local and privately owned retail companies the electricity for the households in apartments is, on the average, 5 per cent more expensive than it is in the municipal companies or utilities.

The estimations results in Tables 2 and 3 show unambiguously that in investor-owned companies and in companies in which an outside investor has a remarkable minority stake the retail prices for households (including heating) and for agricultural consumers are substantially higher than in the municipal companies (which are regarded as a reference). The results are very robust and the price difference is, at its lowest level, above 5 per cent and in many models above 10 per cent. When only ownership indicators and year dummies are controlled, the impact of ownership variables is larger than in those cases in which the model also includes some other regressors. The possession of one's own CHP power is characteristic of municipal utilities, and investor-owned companies tend to be of large size. So it is no wonder that the inclusion of electricity acquiring and size indicator changes the impact estimated. Despite this, coefficients for the variables "investor owned" and "investors have a minority share" remain positive and statistically different from zero. The retail price P7 (for small business users) also tends to be highest when the owner is an outside investor as seen in Table A1. 
Table 2. Determination of the household electricity prices, OLS.

\begin{tabular}{|c|c|c|c|c|c|c|c|c|c|}
\hline \multirow[b]{2}{*}{ local private } & \multicolumn{3}{|c|}{$\log (\mathrm{P} 1)$, apartment } & \multicolumn{3}{|c|}{$\log (\mathrm{P} 2)$, single house } & \multicolumn{3}{|c|}{$\begin{array}{l}\log (\mathrm{P} 3) \text {, single house, direct electric } \\
\text { heating }\end{array}$} \\
\hline & $\begin{array}{l}0.051^{* * *} \\
(0.011)\end{array}$ & $\begin{array}{l}0.042^{* * *} \\
(0.011)\end{array}$ & $\begin{array}{l}0.041^{* * *} \\
(0.012)\end{array}$ & $\begin{array}{l}0.017 * \\
(0.009)\end{array}$ & $\begin{array}{l}0.003 \\
(0.010)\end{array}$ & $\begin{array}{l}0.001 \\
(0.010)\end{array}$ & $\begin{array}{l}0.019^{*} \\
(0.010)\end{array}$ & $\begin{array}{l}0.015 \\
(0.011)\end{array}$ & \begin{tabular}{|l}
0.014 \\
$(0.011)$
\end{tabular} \\
\hline investor owned & $\begin{array}{l}0.156^{* * *} \\
(0.010)\end{array}$ & $\begin{array}{l}0.089^{* * *} \\
(0.015)\end{array}$ & $\begin{array}{l}0.055^{* * *} \\
(0.017)\end{array}$ & $\begin{array}{l}0.121^{* * *} \\
(0.009)\end{array}$ & $\begin{array}{l}0.082^{* * *} \\
(0.013)\end{array}$ & $\begin{array}{l}0.054^{* * *} \\
(0.015)\end{array}$ & $\begin{array}{l}0.141^{* * *} \\
(0.010)\end{array}$ & $\begin{array}{l}0.102 * * * \\
(0.015)\end{array}$ & $\begin{array}{l}0.080^{* * *} \\
(0.016)\end{array}$ \\
\hline $\begin{array}{l}\text { investors have a } \\
\text { minority share }\end{array}$ & $\begin{array}{l}0.104 * * * \\
(0.016)\end{array}$ & $\begin{array}{l}0.107^{* * *} \\
(0.016)\end{array}$ & $\begin{array}{l}0.097^{* * *} \\
(0.017) \\
\end{array}$ & $\begin{array}{l}0.046^{* * *} \\
(0.014)\end{array}$ & $\begin{array}{l}0.047 * * * \\
(0.014)\end{array}$ & $\begin{array}{l}0.052^{* * *} \\
(0.015) \\
\end{array}$ & $\begin{array}{l}0.076^{* * *} \\
(0.016)\end{array}$ & $\begin{array}{l}0.078 * * * \\
(0.016)\end{array}$ & $\begin{array}{l}0.080^{* * *} \\
(0.016) \\
\end{array}$ \\
\hline co-operative & $\begin{array}{l}0.007 \\
(0.019)\end{array}$ & $\begin{array}{l}-0.002 \\
(0.019)\end{array}$ & $\begin{array}{l}0.002 \\
(0.019)\end{array}$ & $\begin{array}{l}-0.023 \\
(0.017) \\
\end{array}$ & \begin{tabular}{|l|}
$-0.036^{* * * *}$ \\
$(0.017)$ \\
\end{tabular} & $\begin{array}{l}-0.022 \\
(0.017) \\
\end{array}$ & $\begin{array}{l}-0.072 * * * \\
(0.018) \\
\end{array}$ & $\begin{array}{l}-0.076^{* * *} \\
(0.018)\end{array}$ & \begin{tabular}{|l}
$-0.066^{* * *}$ \\
$(0.019)$ \\
\end{tabular} \\
\hline medium size & & $\begin{array}{l}-0.109^{* * *} \\
(0.017)\end{array}$ & $\begin{array}{l}-0.101^{* * *} \\
(0.017)\end{array}$ & & $\begin{array}{l}-0.071^{* * *} \\
(0.015) \\
\end{array}$ & $\begin{array}{l}-0.069 * * * \\
(0.015) \\
\end{array}$ & & $\begin{array}{l}-0.060 * * * \\
(0.016)\end{array}$ & $\begin{array}{l}-0.058^{* * *} \\
(0.016) \\
\end{array}$ \\
\hline Small & & $\begin{array}{l}-0.087 * * * \\
(0.018)\end{array}$ & $\begin{array}{l}-0.093^{* * *} \\
(0.018)\end{array}$ & & $\begin{array}{l}-0.042 * * * \\
(0.016)\end{array}$ & $\begin{array}{l}-0.048^{* * *} \\
(0.016)\end{array}$ & & $\begin{array}{l}-0.051^{* * *} \\
(0.017)\end{array}$ & $\begin{array}{l}-0.056^{* * * *} \\
(0.017)\end{array}$ \\
\hline own CHP & & & $\begin{array}{l}-0.012 \\
(0.009)\end{array}$ & & & $\begin{array}{l}0.001 \\
(0.008)\end{array}$ & & & $\begin{array}{l}-0.002 \\
(0.009)\end{array}$ \\
\hline own hydro power & & & $\begin{array}{l}0.034 * * * \\
(0.008)\end{array}$ & & & $\begin{array}{l}0.028^{* * *} \\
(0.007) \\
\end{array}$ & & & $\begin{array}{l}0.023^{* * *} \\
(0.008) \\
\end{array}$ \\
\hline $\begin{array}{l}\text { Stakes in hydro- } \\
\text { power }\end{array}$ & & & $\begin{array}{l}-0.015 \\
(0.010) \\
\end{array}$ & & & $\begin{array}{l}-0.040^{* * *} \\
(0.009) \\
\end{array}$ & & & \begin{tabular}{|l}
$-0.029 * * *$ \\
$(0.010)$ \\
\end{tabular} \\
\hline $\begin{array}{l}\text { stakes of other } \\
\text { power }\end{array}$ & & & $\begin{array}{l}-0.037^{* * *} \\
(0.009)\end{array}$ & & & $\begin{array}{l}-0.018 * * \\
(0.012) \\
\end{array}$ & & & \begin{tabular}{|l|}
$-0.016^{*}$ \\
$(0.008)$ \\
\end{tabular} \\
\hline constant & $\begin{array}{l}1.536^{* * *} \\
(0.012)\end{array}$ & $\begin{array}{l}1.630 * * * \\
(0.020)\end{array}$ & $\begin{array}{l}1.642 * * * \\
(0.022)\end{array}$ & $\begin{array}{l}1.390 * * * \\
(0.010)\end{array}$ & $\begin{array}{l}1.445 * * * \\
(0.017)\end{array}$ & $\begin{array}{l}1.452 * * * \\
(0.019)\end{array}$ & $\begin{array}{l}1.238^{* * *} \\
(0.011)\end{array}$ & $\begin{array}{l}1.299 * * * \\
(0.019)\end{array}$ & $\begin{array}{l}1.297 * * * \\
(0.021) \\
\end{array}$ \\
\hline YEAR dummies & Yes & Yes & Yes & Yes & Yes & Yes & Yes & Yes & Yes \\
\hline $\mathrm{R}^{2}$, adjusted & 0.609 & 0.6238 & 0.6357 & 0.539 & 0.552 & 0.564 & 0.661 & 0.664 & 0.669 \\
\hline $\begin{array}{l}\text { The number of } \\
\text { observations }\end{array}$ & 1060 & 1060 & 1060 & 1060 & 1060 & 1060 & 1060 & 1060 & 1060 \\
\hline
\end{tabular}

Notes: standard errors in parentheses; * Significant at $10 \%, * *$ Significant at $5 \%, * *$ Significant at $1 \%$.

The retail prices under private and local ownership tend to be higher than prices in municipal ownership only for households in an apartment (P1) and for a single electric house with partly accumulating electric heating (P4). The fact that local retail companies in private ownership are located in rural areas is seen in the rather low level of prices for the single house (P2) and for agricultural users (prices P5 and P6). Co-operative ownership lowers the other prices, except P1, with respect to municipal ownership. In Finland the number of co-operatives has, however, declined so much that at the end of the estimation period in 2006 only two co-operatives existed. 
Table 3. Determination of heating and agricultural electricity prices, OLS.

\begin{tabular}{|c|c|c|c|c|c|c|c|c|c|}
\hline \multirow[b]{2}{*}{ local private } & \multicolumn{3}{|c|}{$\begin{array}{l}\log (\mathrm{P} 4), \text { single house, partly } \\
\text { accumulating electric heating }\end{array}$} & \multicolumn{3}{|c|}{$\log (\mathrm{P} 5)$, agriculture fuse } & \multicolumn{3}{|c|}{$\begin{array}{l}\log (\mathrm{P} 6), \text { agriculture direct } \\
\text { electric heating }\end{array}$} \\
\hline & $\begin{array}{l}0.026^{* *} \\
(0.012)\end{array}$ & $\begin{array}{l}0.024 * \\
(0.013)\end{array}$ & $\begin{array}{l}0.022 * \\
(0.013)\end{array}$ & $\begin{array}{l}-0.007 \\
(0.010)\end{array}$ & $\begin{array}{l}-0.022 * * \\
(0.011)\end{array}$ & $\begin{array}{l}-0.021 * \\
(0.011)\end{array}$ & $\begin{array}{l}0.011 \\
(0.010)\end{array}$ & $\begin{array}{l}0.010 \\
(0.011)\end{array}$ & $\begin{array}{l}0.008 \\
(0.011)\end{array}$ \\
\hline investor owned & $\begin{array}{l}0.139^{* * *} \\
(0.011)\end{array}$ & $\begin{array}{l}0.081 * * * \\
(0.017)\end{array}$ & $\begin{array}{l}0.051^{* * *} \\
(0.019)\end{array}$ & $\begin{array}{l}0.100^{* * *} \\
(0.010)\end{array}$ & $\begin{array}{l}0.087 * * * \\
(0.015) \\
\end{array}$ & $\begin{array}{l}0.060^{* * *} \\
(0.016) \\
\end{array}$ & $\begin{array}{l}0.129 * * * \\
(0.009) \\
\end{array}$ & $\begin{array}{l}0.082 * * * \\
(0.017)\end{array}$ & $\begin{array}{l}0.057 * * * \\
(0.016)\end{array}$ \\
\hline $\begin{array}{l}\text { investors have a } \\
\text { minority share }\end{array}$ & $\begin{array}{l}0.093 * * * \\
(0.017)\end{array}$ & $\begin{array}{l}0.095^{* * * *} \\
(0.017)\end{array}$ & $\begin{array}{l}0.094^{* * *} \\
(0.018) \\
\end{array}$ & $\begin{array}{l}0.047 * * * \\
(0.016) \\
\end{array}$ & $\begin{array}{l}0.047 * * * \\
(0.016) \\
\end{array}$ & $\begin{array}{l}0.060 * * * \\
(0.017) \\
\end{array}$ & $\begin{array}{l}0.060 * * * \\
(0.015) \\
\end{array}$ & $\begin{array}{l}0.062 * * * \\
(0.015)\end{array}$ & $\begin{array}{l}0.077 * * * \\
(0.016) \\
\end{array}$ \\
\hline co-operative & $\begin{array}{l}-0.125^{* * *} \\
(0.021)\end{array}$ & $\begin{array}{l}-0.128 * * * \\
(0.021)\end{array}$ & $\begin{array}{l}-0.118 * * * \\
(0.022)\end{array}$ & $\begin{array}{l}-0.078 * * * \\
(0.019) \\
\end{array}$ & \begin{tabular}{|l|}
$-0.092 * * *$ \\
$(0.019)$ \\
\end{tabular} & $\begin{array}{l}-0.073 * * * \\
(0.019) \\
\end{array}$ & $\begin{array}{l}-0.066^{* * * *} \\
(0.018) \\
\end{array}$ & $\begin{array}{l}-0.067 * * * \\
(0.018)\end{array}$ & $\begin{array}{l}-0.048 * * * \\
(0.019) \\
\end{array}$ \\
\hline medium size & & $\begin{array}{l}-0.082 * * * \\
(0.019)\end{array}$ & $\begin{array}{l}-0.077 * * * \\
(0.019)\end{array}$ & & $\begin{array}{l}-0.036^{* *} \\
(0.017)\end{array}$ & $\begin{array}{l}-0.036^{* *} \\
(0.017)\end{array}$ & & $\begin{array}{l}-0.065^{* * * *} \\
(0.017)\end{array}$ & $\begin{array}{l}-0.068 * * * \\
(0.016)\end{array}$ \\
\hline small & & $\begin{array}{l}-0.074 * * * \\
(0.020)\end{array}$ & $\begin{array}{l}-0.081 * * * \\
(0.020)\end{array}$ & & $\begin{array}{l}-0.005 \\
(0.018) \\
\end{array}$ & $\begin{array}{l}-0.009 \\
(0.018)\end{array}$ & & $\begin{array}{l}-0.062 * * * \\
(0.018)\end{array}$ & $\begin{array}{l}-0.072 * * * \\
(0.017)\end{array}$ \\
\hline own CHP & & & $\begin{array}{l}-0.007 \\
(0.010) \\
\end{array}$ & & & $\begin{array}{l}0.017^{*} \\
(0.009) \\
\end{array}$ & & & $\begin{array}{l}0.008 \\
(0.009) \\
\end{array}$ \\
\hline own hydro power & & & $\begin{array}{l}0.030 * * * \\
(0.009) \\
\end{array}$ & & & \begin{tabular}{|l|}
$0.022 * * *$ \\
$(0.008)$ \\
\end{tabular} & & & \begin{tabular}{|l|}
$0.013 *$ \\
$(0.008)$ \\
\end{tabular} \\
\hline $\begin{array}{l}\text { stakes of hydro } \\
\text { power }\end{array}$ & & & $\begin{array}{l}-0.031 * * * \\
(0.011) \\
\end{array}$ & & & \begin{tabular}{|l|}
$-0.036^{* * * *}$ \\
$(0.010)$ \\
\end{tabular} & & & $\begin{array}{l}-0.046^{* * *} \\
(0.010) \\
\end{array}$ \\
\hline $\begin{array}{l}\text { stakes of other } \\
\text { power }\end{array}$ & & & $\begin{array}{l}-0.024 * * \\
(0.010) \\
\end{array}$ & & & $\begin{array}{l}-0.027 * * * \\
(0.008) \\
\end{array}$ & & & $\begin{array}{l}0.015^{*} \\
(0.008) \\
\end{array}$ \\
\hline constant & $\begin{array}{l}1.151^{* * *} \\
(0.012)\end{array}$ & $\begin{array}{l}1.226^{* * *} \\
(0.021) \\
\end{array}$ & $\begin{array}{l}1.236^{* * *} \\
(0.024) \\
\end{array}$ & \begin{tabular}{|l|}
$1.323 * * *$ \\
$(0.012)$ \\
\end{tabular} & \begin{tabular}{|l|}
$1.345^{* * *}$ \\
$(0.019)$ \\
\end{tabular} & \begin{tabular}{|l|}
$1.351 * * *$ \\
$(0.022)$ \\
\end{tabular} & \begin{tabular}{|l|}
$1.246^{* * *}$ \\
$(0.011)$ \\
\end{tabular} & $\begin{array}{l}1.306^{* * *} \\
(0.019) \\
\end{array}$ & $\begin{array}{l}1.320 * * * \\
(0.021) \\
\end{array}$ \\
\hline YEAR dummies & Yes & Yes & Yes & Yes & Yes & Yes & Yes & Yes & Yes \\
\hline $\mathrm{R}^{2}$, adjusted & 0.744 & 0.748 & 0.753 & 0.582 & 0.588 & 0.596 & 0.679 & 0.684 & 0.691 \\
\hline $\begin{array}{l}\text { The number of } \\
\text { observations }\end{array}$ & 954 & 954 & 954 & 1060 & 1060 & 1060 & 954 & 954 & 954 \\
\hline
\end{tabular}

Notes: standard errors in parentheses; * Significant at $10 \%, * *$ Significant at $5 \%, * * *$ Significant at $1 \%$.

Corresponding to expectations, the low-cost sources of electricity usually have a negative impact on prices. In many models this impact does not, however, differ from zero, and sometimes this impact is even positive. The indicators of electricity sources may also clearly describe some other characteristics of retailers like their preferences and pricing strategies. From this it follows that the possession of CHP power - which is typical of municipal utilities - seems to decrease P1 mostly and so the prices of the municipal utilities' favourite customers. Respectively, the fact that one has one's own hydro-power seems to raise the prices considered, which may indicate that one's own hydropower is actually a scarce and meaningless source and that the possessors of it are companies with few alternative, meaningful sources of low-cost electricity.

The negative coefficient estimates for dummies 'small' and 'medium-size' in Tables 2, 3 and A1 are, to some extent, surprising. One could have expected positive estimates as an indicator of the presence 
of scale economies and of its implications on prices. Negative values evidently show that the larger retailers have achieved market power, which is also used in pricing.

Estimation results obtained from the difference-in-differences model are reported in Tables 4, 5 and in Table A2 in the appendix. The results concerning the electricity-acquiring variables and size dummies are similar to the results obtained in pooled regression.

Table 4. Determination of the household electricity prices, OLS.

\begin{tabular}{|c|c|c|c|c|c|c|c|c|c|}
\hline \multirow[b]{2}{*}{ Basic } & \multicolumn{3}{|c|}{$\log (\mathrm{P} 1)$, apartment } & \multicolumn{3}{|c|}{$\log (\mathrm{P} 2)$, single house } & \multicolumn{3}{|c|}{$\log (\mathrm{P} 3)$, direct electric heating } \\
\hline & $\begin{array}{l}-0.161 * * * \\
(0.012)\end{array}$ & $\begin{array}{l}-0.114 * * * \\
(0,014)\end{array}$ & $\begin{array}{l}-0.082 * * * \\
(0.016)\end{array}$ & \begin{tabular}{|l|}
$-0.118^{* * * *}$ \\
$(0.010)$
\end{tabular} & \begin{tabular}{|l|}
$-0.076^{* * *}$ \\
$(0.013)$
\end{tabular} & $\begin{array}{l}-0.055^{* * * *} \\
(0.014)\end{array}$ & $\begin{array}{l}-0.149^{* * *} \\
(0.011)\end{array}$ & $\begin{array}{l}-0.110 * * * \\
(0.014)\end{array}$ & $\begin{array}{l}-0.089 * * * \\
(0.015)\end{array}$ \\
\hline Propens & $\begin{array}{l}-0.135^{* * *} \\
(0.018)\end{array}$ & $\begin{array}{l}-0.086^{* * *} \\
(0.019)\end{array}$ & $\begin{array}{l}-0.069 * * * \\
(0.020)\end{array}$ & \begin{tabular}{|l}
$-0.138 * * *$ \\
$(0.015)$
\end{tabular} & $\begin{array}{l}-0.097 * * * \\
(0.017)\end{array}$ & $\begin{array}{l}-0.073 * * * \\
(0.017)\end{array}$ & $\begin{array}{l}-0.186^{* * *} \\
(0.017)\end{array}$ & $\begin{array}{l}-0.151 * * * \\
(0.018)\end{array}$ & $\begin{array}{l}-0.133 * * * \\
(0.019)\end{array}$ \\
\hline Change & $\begin{array}{l}0.081 * * * \\
(0.019)\end{array}$ & $\begin{array}{l}0.053 * * * \\
(0.019)\end{array}$ & $\begin{array}{l}0.053 * * * \\
(0.019)\end{array}$ & $\begin{array}{l}0.099 * * * \\
(0.016)\end{array}$ & $\begin{array}{l}0.074 * * * \\
(0.016)\end{array}$ & $\begin{array}{l}0.065 * * * \\
(0.017)\end{array}$ & $\begin{array}{l}0.130 * * * \\
(0.018)\end{array}$ & $\begin{array}{l}0.108^{* * *} \\
(0.018)\end{array}$ & $\begin{array}{l}0.104 * * * \\
(0.018)\end{array}$ \\
\hline medium-size & & $\begin{array}{l}-0.098^{* * * *} \\
(0.014)\end{array}$ & $\begin{array}{l}-0.086^{* * *} \\
(0.015)\end{array}$ & & $\begin{array}{l}-0.082 * * * \\
(0.013)\end{array}$ & $\begin{array}{l}-0.068^{* * * *} \\
(0.013)\end{array}$ & & $\begin{array}{l}-0.064 * * * \\
(0.014)\end{array}$ & $\begin{array}{l}-0.052 * * * \\
(0.014)\end{array}$ \\
\hline small & & $\begin{array}{l}-0.062 * * * \\
(0.015)\end{array}$ & $\begin{array}{l}-0.066^{* * * *} \\
(0.015)\end{array}$ & & \begin{tabular}{|l|}
$-0.057 * * *$ \\
$(0.013)$
\end{tabular} & $\begin{array}{l}-0.050 * * * \\
(0.013)\end{array}$ & & $\begin{array}{l}-0.060^{* * *} \\
(0.014)\end{array}$ & $\begin{array}{l}-0.056^{* * *} \\
(0.015)\end{array}$ \\
\hline own CHP & & & $\begin{array}{l}-0.018 * * \\
(0.009)\end{array}$ & & & $\begin{array}{l}0.001 \\
(0.008)\end{array}$ & & & $\begin{array}{l}-0.001 \\
(0.009)\end{array}$ \\
\hline own hydro power & & & $\begin{array}{l}0.029 * * * \\
(0.008)\end{array}$ & & & $\begin{array}{l}0.028 * * * \\
(0.007) \\
\end{array}$ & & & $\begin{array}{l}0.023 * * * \\
(0.008)\end{array}$ \\
\hline $\begin{array}{l}\text { stakes of hydro } \\
\text { power }\end{array}$ & & & \begin{tabular}{|l|}
-0.016 \\
$(0.010)$ \\
\end{tabular} & & & $\begin{array}{l}-0.039 * * * \\
(0.009) \\
\end{array}$ & & & $\begin{array}{l}-0.027 * * * \\
(0.010) \\
\end{array}$ \\
\hline $\begin{array}{l}\text { stakes of other } \\
\text { power }\end{array}$ & & & $\begin{array}{l}-0.028 * * * \\
(0.009)\end{array}$ & & & $\begin{array}{l}-0.022^{* * * *} \\
(0.008)\end{array}$ & & & $\begin{array}{l}-0.024 * * * \\
(0.009)\end{array}$ \\
\hline constant & $\begin{array}{l}1.707 * * * \\
(0.015)\end{array}$ & $\begin{array}{l}1.714 * * * \\
(0.016)\end{array}$ & $\begin{array}{l}1.714 * * * \\
(0.017)\end{array}$ & $\begin{array}{l}1.509 * * * \\
(0.013)\end{array}$ & $\begin{array}{l}1.534 * * * \\
(0.014)\end{array}$ & $\begin{array}{l}1.509 * * * \\
(0.015)\end{array}$ & $\begin{array}{l}1.389 * * * \\
(0.015)\end{array}$ & $\begin{array}{l}1.410 * * * \\
(0.015)\end{array}$ & $\begin{array}{l}1.390 * * * \\
(0.017)\end{array}$ \\
\hline YEAR dummies & Yes & Yes & Yes & Yes & Yes & Yes & Yes & Yes & Yes \\
\hline $\mathrm{R}^{2}$, adjusted & 0.603 & 0.627 & 0.631 & 0.531 & 0.551 & 0.565 & 0.656 & 0.630 & 0.668 \\
\hline $\begin{array}{l}\text { The number of } \\
\text { observations }\end{array}$ & 1060 & 1060 & 1060 & 1060 & 1060 & 1060 & 1060 & 1060 & 1060 \\
\hline
\end{tabular}

Notes: standard errors in parentheses; * Significant at $10 \%, * *$ Significant at $5 \%,{ }^{* *}$ Significant at $1 \%$.

Let us consider more closely, for illustrative purposes, the model in the third column of Table 4 . The value -0.082 for the coefficient of the 'Basic' variable tells us that the price level in the originally locally owned companies (which is not purchased later by an investor owned company) is 8.2 per cent lower than in the originally investor-owned companies (being the reference group). If the retailer is originally locally owned but will, however, be later purchased by outside investors, the price level is at first 6.9 per cent lower than in the originally investor-owned companies as is shown by the value 
-0.069 for the coefficient of 'Propens' variable. The fact that the price level will rise 5.3 per cent when the ownership changes, is indicated by the value 0.053 for the coefficient of 'Change' variable. The coefficient estimates for 'Basic', 'Propens, and 'Change' variables differ from zero at the statistically significant 1 per cent level in all the models considered.

A change of ownership that has been considered often increases prices by over ten per cent, or at the lowest, by more than 5 per cent. The results can be considered very robust. The inclusion of various controllers may change the point estimates, but the estimated values always remain positive and statistically significant at a level better than one per cent.

Table 5. Determination of the household electricity prices, OLS.

\begin{tabular}{|c|c|c|c|c|c|c|c|c|c|}
\hline \multirow[b]{2}{*}{ Basic } & \multicolumn{3}{|c|}{$\begin{array}{l}\log (\mathrm{P} 4), \text { single house, partly } \\
\text { accumulating electric heating }\end{array}$} & \multicolumn{3}{|c|}{$\log (\mathrm{P} 5)$, agriculture fuse } & \multicolumn{3}{|c|}{$\begin{array}{l}\log (\mathrm{P} 6), \text { agriculture direct } \\
\text { electric heating }\end{array}$} \\
\hline & $\begin{array}{l}-0.149 * * * \\
(0.011)\end{array}$ & $\begin{array}{l}-0.103 * * * \\
(0.017)\end{array}$ & $\begin{array}{l}-0.073 * * * \\
(0.018)\end{array}$ & $\begin{array}{l}-0.091 * * * \\
(0.011)\end{array}$ & $\begin{array}{l}-0.065^{* * *} \\
(0.014)\end{array}$ & $\begin{array}{l}-0.048 * * * \\
(0.016)\end{array}$ & $\begin{array}{l}-0.130 * * * \\
(0.011)\end{array}$ & $\begin{array}{l}-0.079 * * * \\
(0.014)\end{array}$ & $\begin{array}{l}-0.064 * * * \\
(0.015)\end{array}$ \\
\hline Propens & $\begin{array}{l}-0.177 * * * \\
(0.021)\end{array}$ & $\begin{array}{l}-0.133 * * * \\
(0.023)\end{array}$ & $\begin{array}{l}-0.112 * * * \\
(0.024)\end{array}$ & $\begin{array}{l}-0.125^{* * *} \\
(0.017)\end{array}$ & $\begin{array}{l}-0.099 * * * \\
(0.019)\end{array}$ & $\begin{array}{l}-0.082 * * * \\
(0.020)\end{array}$ & $\begin{array}{l}-0.188 * * * \\
(0.017)\end{array}$ & $\begin{array}{l}-0.142 * * * \\
(0.019)\end{array}$ & $\begin{array}{l}-0.122 * * * \\
(0.020)\end{array}$ \\
\hline Change & $\begin{array}{l}0.131 * * * \\
(0.021)\end{array}$ & $\begin{array}{l}0.107 * * * \\
(0.022)\end{array}$ & $\begin{array}{l}0.103 * * * \\
(0.022)\end{array}$ & $\begin{array}{l}0.122 * * * \\
(0.018)\end{array}$ & $\begin{array}{l}0.106 * * * \\
(0.019)\end{array}$ & $\begin{array}{l}0.100 * * * \\
(0.019)\end{array}$ & $\begin{array}{l}0.149 * * * \\
(0.018)\end{array}$ & $\begin{array}{l}0.123 * * * \\
(0.018)\end{array}$ & $\begin{array}{l}0.114 * * * \\
(0.018)\end{array}$ \\
\hline medium-size & & $\begin{array}{l}-0.068 * * * \\
(0.016)\end{array}$ & $\begin{array}{l}-0.052 * * * \\
(0.016)\end{array}$ & & $\begin{array}{l}-0.051 * * * \\
(0.014)\end{array}$ & $\begin{array}{l}-0.034 * * \\
(0.014)\end{array}$ & & $\begin{array}{l}-0.070 * * * \\
(0.014)\end{array}$ & $\begin{array}{l}-0.055^{* * *} \\
(0.014)\end{array}$ \\
\hline small & & $\begin{array}{l}-0.065 * * * \\
(0.016)\end{array}$ & $\begin{array}{l}-0.064 * * * \\
(0.017)\end{array}$ & & $\begin{array}{l}-0.036^{* *} \\
(0.015)\end{array}$ & $\begin{array}{l}-0.020 \\
(0.015)\end{array}$ & & $\begin{array}{l}-0.073 * * * \\
(0.014)\end{array}$ & $\begin{array}{l}-0.067 * * * \\
(0.014)\end{array}$ \\
\hline own CHP & & & $\begin{array}{l}-0.009 \\
(0.010)\end{array}$ & & & $\begin{array}{l}0.020 * * \\
(0.009)\end{array}$ & & & $\begin{array}{l}0.005 \\
(0.008)\end{array}$ \\
\hline own hydro power & & & $\begin{array}{l}0.028 * * * \\
(0.009)\end{array}$ & & & $\begin{array}{l}0.025 * * * \\
(0.008)\end{array}$ & & & $\begin{array}{l}0.013 * \\
(0.008)\end{array}$ \\
\hline $\begin{array}{l}\text { stakes of hydro } \\
\text { power }\end{array}$ & & & $\begin{array}{l}-0.031 * * * \\
(0.011)\end{array}$ & & & $\begin{array}{l}-0.036^{* * * *} \\
(0.010)\end{array}$ & & & $\begin{array}{l}-0.038 * * * \\
(0.009)\end{array}$ \\
\hline $\begin{array}{l}\text { stakes of other } \\
\text { power }\end{array}$ & & & $\begin{array}{l}-0.029 * * * \\
(0.010)\end{array}$ & & & $\begin{array}{l}-0.036^{* * *} \\
(0.009)\end{array}$ & & & $\begin{array}{l}-0.023 * * * \\
(0.008)\end{array}$ \\
\hline constant & $\begin{array}{l}1.301 * * * \\
(0.016)\end{array}$ & $\begin{array}{l}1.319 * * * \\
(0.017)\end{array}$ & $\begin{array}{l}1.296 * * * \\
(0.019)\end{array}$ & $\begin{array}{l}1.410 * * * \\
(0.015)\end{array}$ & $\begin{array}{l}1.426 * * * \\
(0.016)\end{array}$ & $\begin{array}{l}1.400 * * * \\
(0.017)\end{array}$ & $\begin{array}{l}1.375 * * * \\
(0.014)\end{array}$ & $\begin{array}{l}1.394 * * * \\
(0.014)\end{array}$ & $\begin{array}{l}1.383 * * * \\
(0.016)\end{array}$ \\
\hline YEAR dummies & Yes & Yes & Yes & Yes & Yes & Yes & Yes & Yes & Yes \\
\hline $\mathrm{R}^{2}$, adjusted & 0.733 & 0.738 & 0.743 & 0.574 & 0.579 & 0.592 & 0.676 & 0.685 & 0.692 \\
\hline $\begin{array}{l}\text { The number of } \\
\text { observations }\end{array}$ & 954 & 954 & 954 & 1060 & 1060 & 1060 & 954 & 954 & 954 \\
\hline
\end{tabular}




\section{CONCLUSIONS}

This study has shown that ownership has a strong impact on retail prices in the legally free Finnish market. Local ownership which evidently makes a retailer deviate from pro-profit orientation leads to lower prices. This also proves that the efficiency of municipal and other non-for-profit firms cannot be very low compared with investor-owned companies. Otherwise, the heavy cost-structure would force the prices to be set at a relatively high level. The results also show that local firms have evidently obtained their ability to keep prices at low levels by investing in their own generation and other low-cost sources of electricity.

To some extent the results obtained oppose the conventional thinking, according to which, competition is the main mechanism for restricting price rises. The finding that local ownership lowers the price level in Finland shows that self-regulation retailers can correct the defects in the competition mechanism. This may even partly explain the passivity of clients. At least this phenomenon relieves the adverse effects of weak competition accrued from customers' reluctance to switch from one retailer to another.

In popular discussion in Finland at least it is, on the other hand, argued that the observed average cost pricing in Finland - which does not solely rely on the wholesale prices - creates welfare losses. According to the critics, investments are not properly allocated, owing to distorting pricing. This is also regarded as a handicap to achieve an energy-saving goal and the targets to move people to use clean energy. To answer these questions is outside the scope of this study. But this would be an interesting starting point for future research. As concerns the impacts of pricing strategies and ownership structures on the incentives to invest in power plants and to react to the signals of environmental taxes it is difficult to say anything without a proper empirical study. In this context the behaviour of retailers could also deviate from that rationality which standard profit maximization would suggest. 


\section{REFERENCES}

Amundsen, E.S., Bergman, L., 2007. Integration of multiple national markets for electricity: The case of Norway and Sweden. Energy Policy, 35, 3383-3394.

Ashenfelter, O., Card, D., 1985. Using the longitudinal structure of earnings to estimate the effect of training programs. Review of Economics and Statistics, 67, 648-660.

Berry, D.M., 1994. Private ownership form and productive efficiency: electric cooperatives versus investor-owned utilities. Journal of Regulatory Economics, 6, 399-420.

Bertrand, O., Zitouna, H., 2008. Domestic versus cross-border acquisitions: which impact on the target firm's performance? Applied Economics, 40, 2221-2238.

Defeuilley, C., 2008). Retail competition in electricity market. Energy Policy, 37, 377-386.

Energy Information Administration (EIA), 2007. Electric power industry overview 2007, (www.eia.doe.gov/cneaf/electricity).

Energy Market Authority, 2005. The functioning of electricity retail market (in Finnish: "Sähkön vähittäismyyntimarkkinoiden toimivuus"), Dnro 1131/2005.

European Commission, 2004. Towards competitive and regulated European electricity and gas market, memo Directorate general for Energy and Transport.

The Finnish Electricity Association (Pertti Lindberg and Laura Koskenrouta) and Statistics Finland (Leena Timonen), 2003. Client activity in the electricity market (in Finnish: Asiakasaktiivisuus sähkömarkkinoilla), 4.6.2003.

Giuletti, M., Otero, J., Waterson, M., 2010. Supply competition and price behaviour under competition in the UK electricity supply industry. Oxford Economic Papers (forthcoming).

Green, R., 1994. The English electricity industry in the 1990s, Manuscript, Cambridge, August 1994.

Haushalter, G.D., 2000. Financing policy, basic risk, and corporate hedging: Evidence from oil and gas producers. The Journal of Finance, 55, 107-152.

Hjalmarsson, L., Veiderpass, A., 1992. Productivity in the Swedish electricity retail distribution. Scandinavian Journal of Economics, 94, 193-205.

Hollas, D.R, Stansell, S.R. and Claggett Jr, E.T., 1994. Ownership form and rate structure: an examination of cooperative and municipal electric distribution utilities. Southern Economic Journal, 61, 519-529.

Johnsen, T.A., Olsen, O.J., 2008. The relationship between wholesale and retail electricity prices to households in the Nordic countries, unpublished manuscript. 
Kang, L., Zarnikau, J., 2009. Did the expiration of retail price caps affect prices in the restructured Texas electricity market? Energy Policy, 37, 1713-1717.

Kinnunen, K., 2004., Competition in the electricity market, (in Finnish "Kilpailullisuus sähkömarkkinoilla"), National Consumer Research Centre, Publications 9:2004.

Kumbhakar, S.C., Hjalmarsson, L., 1998. Relative performance of public and private ownership under yardstick competition: electricity retail distribution. European Economic Review, 42, 97-122.

Lewis, P., Pakkanen, M., Närvä, T., Hernesniemi, L., Partanen, J., Viljanen, S., Honkapuro, S., Tahvanainen, K., Jylhä, R.,(2007). A report on the development in the electricity and natural gas market and on the experiences obtained when applying electricity and gas market acts (in Finnish "Selvitys sähkö- ja maakaasumarkkinoiden kehityksestä sekä sähkö- ja maakaasumarkkinalakien soveltamisesta saaduista kokemuksista”). KTM Publications, 2/2007, Energy Market Department.

Lehto, E., 1994. The price setting of regional electricity utilities (in Finnish: Alueellisten sähkölaitosten sähkön hinnoittelu), Labour Institute for Economic Research, Studies 49.

Littlechild, S., 2006. Competition and contracts in the Nordic residential electricity markets. Utilities Policy, 14, 135-147.

Nordic Energy Regulators, 2006. The integrated Nordic end-user electricity market. Report 2/2006.

Olsen, O.J, Johnsen, T.A, Lewis, P.E., 2006., A mixed Nordic experience: implementing competitive retail electricity markets for household customers. The Electricity Journal, 19, 37-44.

Perrels, A., Kemppi, H., 2003. Liberalised electricity markets - strengths and weaknesses in Finland and Nordpool. VATT-research Papers 97.

Petersen, H.C, 2006. Rates and tariff structures: Investor-owned utilities vs. rural electric cooperatives. Agribusiness 7, 597-601.

Von Der Fehr, N-H., Hansen, P.V., 2008. Electricity retailing in Norway, Oslo University, Department of Economics, Memorandum, 02/2009

Zarnikau, J., Fox, M., Smolen, P., 2007. Trends in prices to commercial energy consumers in the competitive Texas electricity market. Energy Policy, 35, 4332-4339. 


\section{APPENDIX A.}

\section{The auxiliary results}

Table A1. Determination of electricity prices for small-scale industry, $\log (\mathrm{P} 7)$, OLS.

\begin{tabular}{|c|c|c|c|}
\hline local private & $\begin{array}{l}-0.012 \\
(0.013) \\
\end{array}$ & $\begin{array}{l}0.011 \\
(0.014)\end{array}$ & $\begin{array}{l}0.034^{* *} \\
(0.014)\end{array}$ \\
\hline investor owned & $\begin{array}{l}0.102^{* * *} \\
(0.012)\end{array}$ & $\begin{array}{l}0.047 * * \\
(0.018)\end{array}$ & $\begin{array}{l}0.035^{*} \\
(0.020)\end{array}$ \\
\hline $\begin{array}{l}\text { investors have a minority } \\
\text { share }\end{array}$ & $\begin{array}{l}-0.015 \\
(0.020) \\
\end{array}$ & $\begin{array}{l}-0.011 \\
(0.019) \\
\end{array}$ & $\begin{array}{l}0.035^{*} \\
(0.020) \\
\end{array}$ \\
\hline co-operative & $\begin{array}{l}-0.074 * * \\
(0.023)\end{array}$ & $\begin{array}{l}-0.053 * * \\
(0.023)\end{array}$ & $\begin{array}{l}-0.015 \\
(0.022)\end{array}$ \\
\hline medium size & & $\begin{array}{l}-0.056^{* * *} \\
(0.020)\end{array}$ & $\begin{array}{l}-0.061 * * * \\
(0.020)\end{array}$ \\
\hline small & & $\begin{array}{l}-0.100 * * * \\
(0.021)\end{array}$ & $\begin{array}{l}-0.080 * * * \\
(0.021)\end{array}$ \\
\hline own CHP & & & $\begin{array}{l}0.094 * * * \\
(0.011) \\
\end{array}$ \\
\hline own hydro power & & & $\begin{array}{l}0.041 * * * \\
(0.009)\end{array}$ \\
\hline stakes of hydro power & & & $\begin{array}{l}-0.023^{*} \\
(0.012) \\
\end{array}$ \\
\hline stakes of other power & & & $\begin{array}{l}-0.041 * * * \\
(0.010)\end{array}$ \\
\hline constant & $\begin{array}{l}1.298^{* * *} \\
(0.014)\end{array}$ & $\begin{array}{l}1.368^{* * *} \\
(0.024)\end{array}$ & $\begin{array}{l}1.317^{* * *} \\
(0.026)\end{array}$ \\
\hline YEAR dummies & Yes & Yes & Yes \\
\hline $\mathrm{R}^{2}$, adjusted & 0.567 & 0.578 & 0.608 \\
\hline $\begin{array}{l}\text { The number of } \\
\text { observations }\end{array}$ & 1058 & 1058 & 1058 \\
\hline
\end{tabular}

Notes: standard errors in parentheses; * Significant at $10 \%$,

** Significant at $5 \%,{ }^{* * *}$ Significant at $1 \%$. 
Table A2. Determination of electricity prices for small-scale industry, log (P7), OLS.

\begin{tabular}{|c|c|c|c|}
\hline Basic & $\begin{array}{l}-0.086^{* * *} \\
(0.014)\end{array}$ & $\begin{array}{l}-0.012 \\
(0.017)\end{array}$ & $\begin{array}{l}-0.021 \\
(0.018)\end{array}$ \\
\hline Propens & $\begin{array}{l}-0.149^{* * *} \\
(0.021)\end{array}$ & $\begin{array}{l}-0.093^{* * *} \\
(0.023)\end{array}$ & $\begin{array}{l}-0.102^{* * *} \\
(0.023)\end{array}$ \\
\hline Change & $\begin{array}{l}0.126 * * * \\
(0.022)\end{array}$ & $\begin{array}{l}0.090 * * * \\
(0.022)\end{array}$ & $\begin{array}{l}0.093 * * * \\
(0.022)\end{array}$ \\
\hline medium-size & & $\begin{array}{l}-0.083 * * * \\
(0.017)\end{array}$ & $\begin{array}{l}-0.062^{* * *} \\
(0.017)\end{array}$ \\
\hline small & & $\begin{array}{l}-0.134 * * * \\
(0.018)\end{array}$ & $\begin{array}{l}-0.084 * * * \\
(0.018)\end{array}$ \\
\hline own CHP & & & $\begin{array}{l}0.086^{* * *} \\
(0.011)\end{array}$ \\
\hline own hydro power & & & $\begin{array}{l}0.040 * * * \\
(0.009)\end{array}$ \\
\hline stakes of hydro power & & & $\begin{array}{l}-0.014 \\
(0.012)\end{array}$ \\
\hline stakes of other power & & & $\begin{array}{l}-0.054 * * * \\
(0.010)\end{array}$ \\
\hline constant & $\begin{array}{l}1.379 * * * \\
(0.018)\end{array}$ & $\begin{array}{l}1.411 * * * \\
(0.019)\end{array}$ & $\begin{array}{l}1.359 * * * \\
(0.020)\end{array}$ \\
\hline YEAR dummies & Yes & Yes & Yes \\
\hline $\mathrm{R}^{2}$, adjusted & 0.556 & 0.582 & 0.614 \\
\hline The number of observations & 1058 & 1058 & 1058 \\
\hline
\end{tabular}

Notes: standard errors in parentheses; * Significant at $10 \%$, ** Significant at $5 \%$, *** Significant at $1 \%$. 